\title{
Utility of p57KIP2 and Her-2 Fluorescence in Situ Hybridization in Differentiating Partial from Complete Hydatidiform Mole
}

\author{
Michele H. Diwa, ${ }^{1}$ Min-A Kim, ${ }^{2}$ Jose Maria C. Avila, ${ }^{1}$ David G. Pedroza ${ }^{3}$ and Michelle Anne M. Encinas-Latoy ${ }^{1}$ \\ ${ }^{1}$ Department of Pathology, College of Medicine, University of the Philippines Manila \\ ${ }^{2}$ Department of Pathology, College of Medicine, Seoul National University, Seoul, Korea \\ ${ }^{3}$ Department of Laboratories, Philippine General Hospital
}

\begin{abstract}
Introduction. Hydatidiform mole (HM) is an abnormal gestation characterized by significant hydropic enlargement, trophoblastic proliferation and atypia involving part or all of the chorionic villi. The diagnosis and classification of hydatidiform moles is subject to great inter-observer variability due to significant morphologic overlaps. This study aims to evaluate the utility of p57KIP2 immunohistochemistry and ploidy by Her- $2 \mathrm{FISH}$ in refining the diagnosis of molar tissues.
\end{abstract}

Method. 113 and 78 molar cases were retrieved from the archives of the Histopathology Section of the Philippine General Hospital and Pathology Department of Seoul National University Hospital, respectively. TMA sections were submitted for immunohistochemical analysis for p57KIP2. Ploidy was determined by fluorescence in situ hybridization using Her-2 probe. An interrater reliability analysis was done using the Kappa statistics with $95 \%$ confidence interval.

Results. All 68 (100\%) cases diagnosed as $\mathrm{CH}$ were negative for p57KIP2 staining and are diploid. Among the 54 cases of PH, only $1(2 \%)$ is positive for p57KIP2 and is diploid. The interrater reliability between $\mathrm{p} 57 \mathrm{KIP} 2$ and Her-2 FISH ploidy results is 0.66 ( $<.0 .001), 95 \% \mathrm{Cl}(0.02,1.00)$ which is considered "fair to good." The kappa value between review diagnosis and p57KIP2 is 0.024 while the kappa between review diagnosis and Her-2 FISH ploidy is 0.050 both signifying poor agreement beyond chance.

Conclusion. Morphologic assessment alone may not be sufficient in problematic cases. p57KIP2 in conjunction with by Her-2 FISH are good adjuncts in the diagnosis and classification of hydatidiform mole.

Key Words: hydatidiform mole, p57KIP2, ploidy

\section{Introduction}

Hydatidiform mole (HM) is an abnormal gestation characterized by significant hydropic enlargement, trophoblastic proliferation and atypia involving part or all of

\footnotetext{
Corresponding author: Michele H. Diwa, MD

Department of Pathology

College of Medicine

University of the Philippines Manila

547 Pedro Gil, St. Ermita, Manila 1000 Philippines

Telephone: +6325264550

Email: mitchdiwa@yahoo.com
}

the chorionic villi. ${ }^{1,2}$ They carry significant risk for developing persistent gestational trophoblastic disease in the form of a persistent mole in the uterine cavity, an invasive mole or a choriocarcinoma. ${ }^{1}$ Choriocarcinoma arises in $10 \%-30 \%$ of complete hydatidiform moles and rarely, after a partial hydatidiform mole in $0.5-5 \%$ of cases. ${ }^{3}$ Thus, as much as discriminating molar pregnancy from a non-molar gestation is essential, distinction between partial and complete hydatidiform mole is also significant and has great impact in the prognosis of these patients. ${ }^{3,45}$ However, the diagnosis and classification of hydatidiform moles is subject to great interobserver variability due to significant morphologic overlaps. ${ }^{6}$

Ancillary techniques such as immunohistochemistry and more sophisticated methods like electron microscopy, DNA flow or image cytometry, chromosome and fluorescence in situ hybridization, polymerase chain reaction-based genotyping and cytogenetics may be utilized to arrive at a more definitive diagnosis. ${ }^{4,-11}$ However, most, if not all of these are technically cumbersome, expensive and are unlikely to become available in most laboratories.

Several studies have been conducted to prove the utility of p57KIP2 immunohistochemistry in the sub-classification of molar pregnancy. $4,6,8,10-13$ p57KIP2 gene (CDKN1C) is a cyclin-dependent kinase inhibitor and tumor suppressor gene located on chromosome $11 \mathrm{p} 15.5 .{ }^{11,14}$ It is paternally imprinted but maternally expressed. ${ }^{11}$ Since CMs contain only paternal genes, p57KIP2 gene should be underexpressed, in contrast to PM and HA which have contributions from both maternal and paternal genomes. However, this may pose a problem when the diagnostic dilemma is between a $\mathrm{PH}$ and an HA because immunohistochemical staining for p57KIP2 cannot distinguish between the two as both are immunoreactive. In these instances, other ancillary methods that detect ploidy of gestational products should be helpful.

Ploidy studies take advantage of the fact that different pathologic conditions have different genetic features. A vast majority of $\mathrm{CH}$ are diploid gestations and of pure androgenetic origin. It develops when an empty egg is fertilized by one or two spermatozoa resulting in two complete male-derived haploid chromosomes thus resulting to diploid gestation. Most PH are triploid gestations and are formed from fertilization of an ovum by two spermatozoa 
but fertilization of an egg by a diploid sperm cannot be ruled out entirely. ${ }^{15} \mathrm{HA}$, on the other hand, is also diploid.

Whereas multiple technologies are available to determine ploidy, they are expensive, time and labor intensive and are not catered by most laboratories. ${ }^{16}$

Several studies have evaluated the utility of FISH using different probes to determine ploidy of hydatidiform moles and other gestational trophoblastic neoplasms including a recent study that was conducted by Le Gallo et al that used Her-2 probe. ${ }^{4}$ Her-2/neu is an oncogene located on chromosome $17 q 21$ that is amplified in $20-30 \%$ of breast cancer cases. Since it is widely used nowadays in the management of breast cancer, Her-2 probe is readily available in most laboratories compared to other probes that were suggested in past studies. In developing countries where the availability of the different molecular methods is limited, Her-2 FISH is probably one of the most readily available due to its wide application in breast cancer. This method is a useful tool in cases of diagnostic dilemma especially between partial mole and hydropic abortus which cannot be differentiated by immunohistochemistry.

In light of this information, we set to evaluate the utility of p57KIP2 immunohistochemistry and ploidy by Her-2 FISH in refining the diagnosis of molar tissues.

\section{Methods}

\section{Case Selection}

113 and 78 molar cases were retrieved from the archives of the Histopathology Section of the University of the PhilippinesPhilippine General Hospital and Pathology Department of Seoul National University Hospital, respectively. Two pathologists reviewed all cases simultaneously using a multi-header microscope and rendered a review diagnosis based on established criteria. ${ }^{1,15,16}$ Both pathologists were blinded with regard to the previous histopathologic diagnosis of the cases. Cases wherein there were complete agreement between the two pathologists 'diagnoses were included in the study. The study was approved by the institutional review board of Seoul National University.

\section{Tissue Microarray}

Three areas containing villous cytotrophoblasts and mesenchymal cells were marked on the hematoxylin and eosin stained slides. Two-millimeter cores were obtained from the respective paraffin-embedded, formalin-fixed blocks, using a manual tissue arrayer. These tissue cores were inserted into a recipient paraffin block.

\section{Immunohistochemistry}

TMA sections were submitted for immunohistochemical analysis for p57KIP2 (DAKO, Freemont, USA, dilution 1:200) Three-micrometer thick TMA sections were mounted on positively charged slides and dried inside the oven for one hour. Antigen retrieval was done using standard procedure. Slides were stained using a DAKO autostainer.

Immunoreactivity was assessed among the nuclei of cytotrophoblasts and villous mesenchymal cells using a twotiered system (Negative and Positive). A case is considered positive if nuclear immunoreactivity is observed in at least $50 \%$ of the cells.

\section{Her-2 Fluorescent-In-situ Hybridization for Ploidy Determination}

Ploidy was determined by fluorescence in situ hybridization using Her-2 probe according to manufacturer's procedure (Pathvysion Her-2 DNA Probe Kit, Abbott-Vysis, Downers Grove, IL, USA). In each case, signals of 150 tumor nuclei of villous and cytotrophoblastic cells (50 nuclei for each core) were counted using a BX51TRF microscope (Olympus, Japan) equipped with DAPI, green, orange, aqua, and triple-pass (DAPI/Green/Orange) filters (Abbott-Vysis). Since not all cores have interpretable signals, the average number of signals per case was obtained.

Detection of two green signals was considered as diploid. Cases wherein there were more than $10 \%$ of the villous stromal and cytotrophoblastic cells with 3 or 4 intranuclear signals were interpreted as triploid and tetraploid, respectively. Tissues with very weak or without signals were reprocessed.

\section{Statistical Analysis}

An interrater reliability analysis using the Kappa statistic was computed using SPSS version 17 to determine consistency among raters. Kappa values cannot exceed the range $-1.0-+1.0$ and a value of 0 is equivalent to chance. By arbitrary convention, k value of $<0.40$ was considered "poor," $0.41-0.75$ was "fair to good" and $\geq 0.75$ was "excellent."17 Ninety five percent confidence intervals (CIs) was also calculated using SAS version 9.0.

\section{Results}

\section{Histopathology}

After histopathologic review of the cases, only 122 out of the 191 cases were included. Of the 122 cases, 68 were diagnosed as complete mole and 54 were diagnosed as partial mole. Reasons for exclusion of cases were missing paraffin blocks, inadequate amount of tissue for immunohistochemistry and FISH and no consensus in the review diagnoses between the pathologists. Diagnosis was revised in 22 cases. Seven cases with original diagnosis of "hydatidiform mole" were revised to $\mathrm{CH}$ (case nos. 1, 2, 3, 4, $7,8)$ and PH (case no. 16); one case diagnosed as "products of conception" was revised to $\mathrm{PH}$ (case no. 13); 10 cases diagnosed as $\mathrm{CH}$ were revised to $\mathrm{PH}$ (case nos. 714, 29, 31, $33,38,40,54,64,72,74) ; 4$ cases diagnosed as PH were revised to $\mathrm{CH}$ (case nos. 15, 17, 26, 78). 


\section{p57KIP2 Expression}

Table 1 shows the results immunohistochemistry and ploidy results of all cases. p57KIP2 expression was observed in only $1(2 \%)$ of the 54 cases diagnosed as $\mathrm{PH}$ (Figure 1). All 68 (100\%) cases diagnosed as $\mathrm{CH}$ were negative for p57KIP2 staining (Figure 2). Nuclear reactivity was seen in intermediate trophoblasts and served as internal positive control. Syncytiotrophoblasts were negative in all cases.

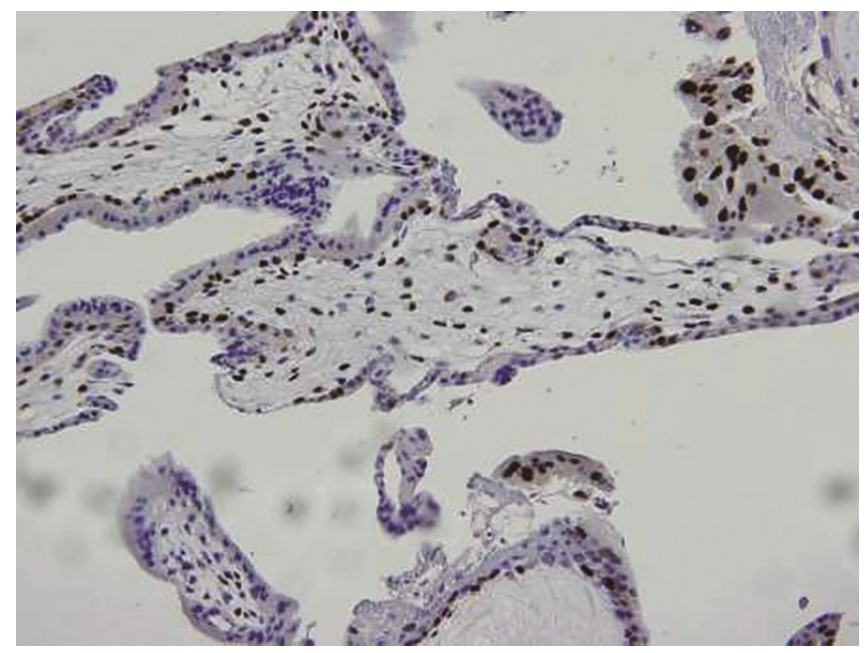

Figure 1. Partial hydatidiform mole. Positive for p57KIP2 immunostain in cytotrophoblasts and villous mesenchymal cells. (400x).

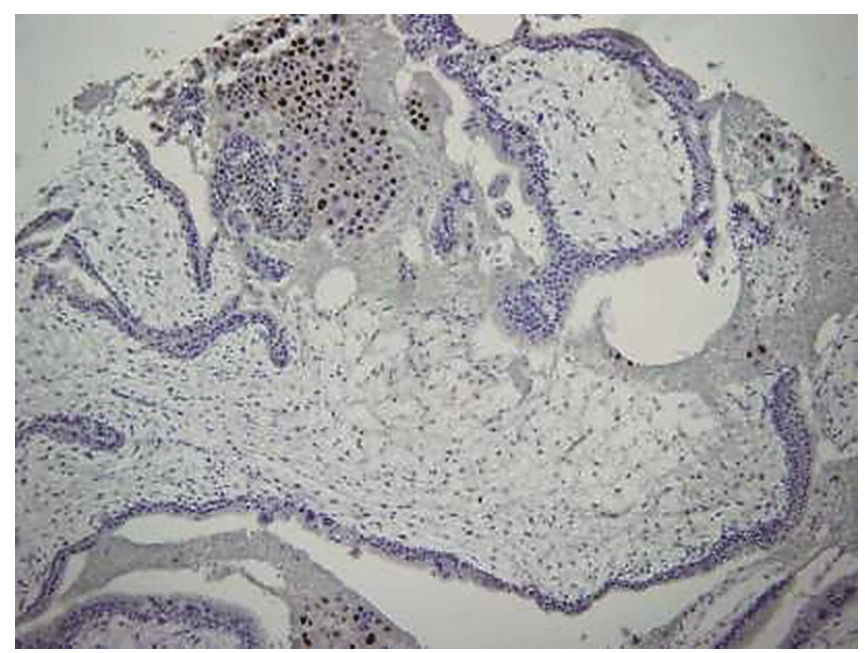

Figure 2. Complete hydatidiform mole. Negative to p57KIP2 immunostain in cytotrophoblasts and villous mesenchymal cells. Intermediate trophoblasts are positive. (40x).

\section{Ploidy study by Her-2 FISH}

FISH was not successful in 5 cases (case nos. 14, 21, 79, $98,121)$. Diploid cases consisted of two green signals (Figure 3) in $32-96 \%$ of the cells counted and were seen in all 68 cases diagnosed as $\mathrm{CH}$ and 53 cases diagnosed as $\mathrm{PH}$. Triploidy consisted of three green signals in at least $20 \%$ of the cells and was seen in only one case diagnosed as $\mathrm{PH}$ (Figure 4). There was no triploidy observed among cases diagnosed as $\mathrm{CH}$.

Table 1. Morphologic Parameters used in evaluation of discordant cases

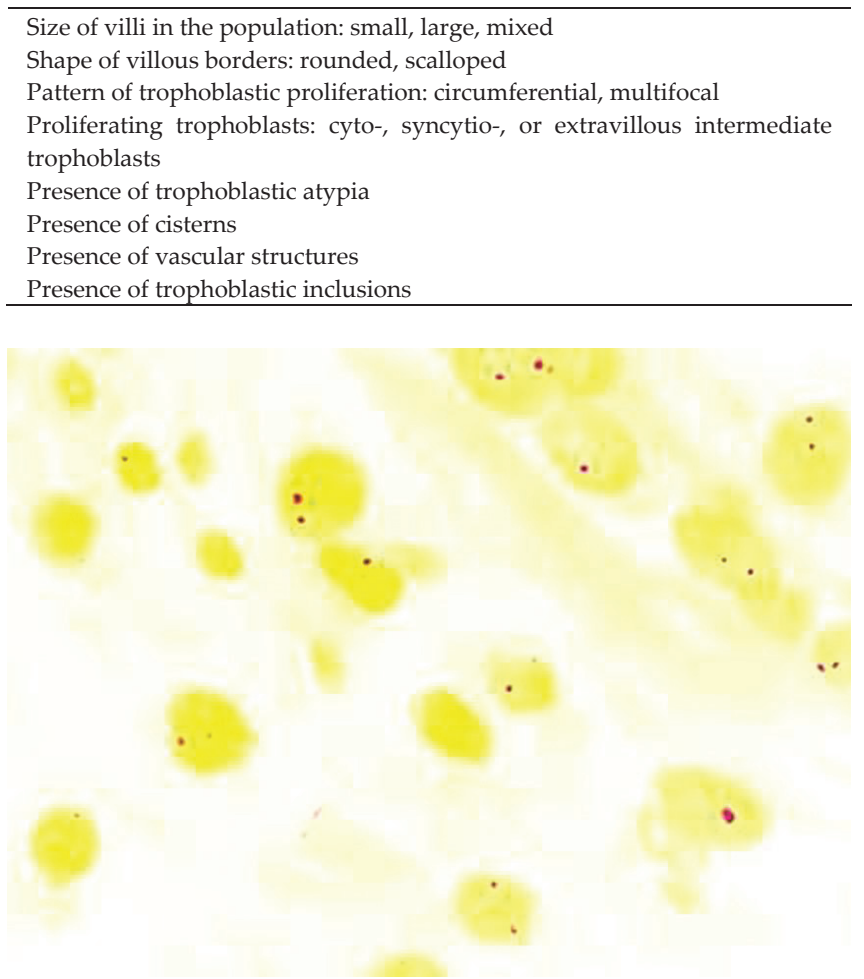

Figure 3. Complete hydatidiform mole. Her-2 FISH test showing two (CEP 17) green signals (diploid). (1000x).

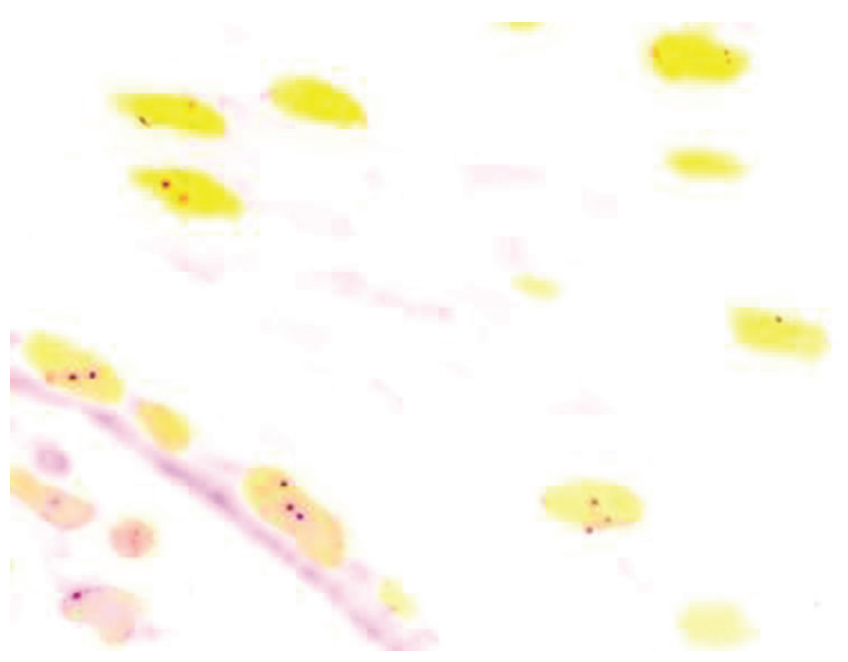

Figure 4. Partial hydatidiform mole. Her-2 FISH shows three (DEP 17) green signals (triploid). (1000x). 
Table 2. Summary of the diagnostic utility of complementary use of p57KIP2 and Her-2 FISH ploidy analysis

\begin{tabular}{|c|c|c|c|c|}
\hline Case No. & $\begin{array}{c}\text { Review } \\
\text { Diagnosis }\end{array}$ & $\begin{array}{l}\text { p57KIP2 } \\
\text { staining }\end{array}$ & Her-2 FISH & $\begin{array}{c}\text { Final } \\
\text { Diagnosis }\end{array}$ \\
\hline $10^{*}$ & PH & - & $\mathrm{D}$ & $\mathrm{CH}$ \\
\hline $14^{*}$ & PH & - & No Signal & $\mathrm{CH}$ \\
\hline $16^{*}$ & PH & - & D & $\mathrm{CH}$ \\
\hline $21^{*}$ & PH & - & No signal & \\
\hline $27^{*}$ & $\mathrm{PH}$ & - & D & $\mathrm{CH}$ \\
\hline $29^{*}$ & $\mathrm{PH}$ & - & $\mathrm{D}$ & $\mathrm{CH}$ \\
\hline $31^{*}$ & $\mathrm{PH}$ & - & $\mathrm{D}$ & $\mathrm{CH}$ \\
\hline $33^{*}$ & $\mathrm{PH}$ & - & $\mathrm{D}$ & $\mathrm{CH}$ \\
\hline $38^{*}$ & PH & - & $\mathrm{D}$ & $\mathrm{CH}$ \\
\hline $40^{*}$ & PH & - & $\mathrm{D}$ & $\mathrm{CH}$ \\
\hline $41^{*}$ & PH & - & D & $\mathrm{CH}$ \\
\hline $54^{*}$ & $\mathrm{PH}$ & - & $\mathrm{D}$ & $\mathrm{CH}$ \\
\hline $64^{*}$ & $\mathrm{PH}$ & - & $\mathrm{D}$ & $\mathrm{CH}$ \\
\hline $72^{*}$ & $\mathrm{PH}$ & - & D & $\mathrm{CH}$ \\
\hline $74^{*}$ & $\mathrm{PH}$ & - & $\mathrm{D}$ & $\mathrm{CH}$ \\
\hline $79^{*}$ & PH & (+) CT (-) VM & No Signal & $\mathrm{CH}$ \\
\hline $80^{*}$ & $\mathrm{PH}$ & - & D & $\mathrm{CH}$ \\
\hline $81^{*}$ & $\mathrm{PH}$ & - & $\mathrm{D}$ & $\mathrm{CH}$ \\
\hline $82^{*}$ & $\mathrm{PH}$ & - & $\mathrm{D}$ & $\mathrm{CH}$ \\
\hline $83^{*}$ & $\mathrm{PH}$ & - & $\mathrm{D}$ & $\mathrm{CH}$ \\
\hline $86^{*}$ & $\mathrm{PH}$ & - & $\mathrm{D}$ & $\mathrm{CH}$ \\
\hline $88^{*}$ & $\mathrm{PH}$ & - & $\mathrm{D}$ & $\mathrm{CH}$ \\
\hline $89^{*}$ & PH & - & $\mathrm{D}$ & $\mathrm{CH}$ \\
\hline $90^{*}$ & $\mathrm{PH}$ & - & D & $\mathrm{CH}$ \\
\hline $91^{*}$ & $\mathrm{PH}$ & - & $\mathrm{D}$ & $\mathrm{CH}$ \\
\hline $93^{*}$ & $\mathrm{PH}$ & - & D & $\mathrm{CH}$ \\
\hline $94^{*}$ & $\mathrm{PH}$ & - & $\mathrm{D}$ & $\mathrm{CH}$ \\
\hline $95^{*}$ & PH & - & $\mathrm{D}$ & $\mathrm{CH}$ \\
\hline $97^{*}$ & PH & - & $\mathrm{D}$ & $\mathrm{CH}$ \\
\hline $98^{*}$ & PH & - & No Signal & $\mathrm{CH}$ \\
\hline $99^{*}$ & $\mathrm{PH}$ & - & D & $\mathrm{CH}$ \\
\hline $100^{*}$ & $\mathrm{PH}$ & - & $\mathrm{D}$ & $\mathrm{CH}$ \\
\hline $101^{*}$ & $\mathrm{PH}$ & - & $\mathrm{D}$ & $\mathrm{CH}$ \\
\hline $102^{*}$ & $\mathrm{PH}$ & - & $\mathrm{D}$ & $\mathrm{CH}$ \\
\hline $103^{*}$ & $\mathrm{PH}$ & - & $\mathrm{D}$ & $\mathrm{CH}$ \\
\hline $104^{*}$ & PH & - & $\mathrm{D}$ & $\mathrm{CH}$ \\
\hline $105^{*}$ & $\mathrm{PH}$ & - & $\mathrm{D}$ & $\mathrm{CH}$ \\
\hline $106^{*}$ & $\mathrm{PH}$ & - & $\mathrm{D}$ & $\mathrm{CH}$ \\
\hline $107^{*}$ & $\mathrm{PH}$ & - & $\mathrm{D}$ & $\mathrm{CH}$ \\
\hline $108^{*}$ & $\mathrm{PH}$ & - & D & $\mathrm{CH}$ \\
\hline $109^{*}$ & PH & - & $\mathrm{D}$ & $\mathrm{CH}$ \\
\hline $110^{*}$ & PH & - & $\mathrm{D}$ & $\mathrm{CH}$ \\
\hline $111^{*}$ & PH & - & $\mathrm{D}$ & $\mathrm{CH}$ \\
\hline $112^{*}$ & $\mathrm{PH}$ & - & $\mathrm{D}$ & $\mathrm{CH}$ \\
\hline $113^{*}$ & $\mathrm{PH}$ & $(+) \mathrm{CT}(-) \mathrm{VM}$ & $\mathrm{D}$ & $\mathrm{CH}$ \\
\hline $114^{*}$ & $\mathrm{PH}$ & - & $\mathrm{D}$ & $\mathrm{CH}$ \\
\hline $115^{*}$ & $\mathrm{PH}$ & - & D & $\mathrm{CH}$ \\
\hline $116^{*}$ & $\mathrm{PH}$ & - & D & $\mathrm{CH}$ \\
\hline $117^{*}$ & $\mathrm{PH}$ & - & $\mathrm{D}$ & $\mathrm{CH}$ \\
\hline $118^{*}$ & PH & - & $\mathrm{D}$ & $\mathrm{CH}$ \\
\hline $119^{*}$ & $\mathrm{PH}$ & - & $\mathrm{D}$ & $\mathrm{CH}$ \\
\hline $120^{*}$ & $\mathrm{PH}$ & - & $\mathrm{D}$ & $\mathrm{CH}$ \\
\hline $121^{*}$ & $\mathrm{PH}$ & - & No Signal & $\mathrm{CH}$ \\
\hline $122^{*}$ & $\mathrm{PH}$ & $(+) \mathrm{CT}(-) \mathrm{VM}$ & D & $\mathrm{CH}$ \\
\hline
\end{tabular}

(Legend: PH - Partial hydatidiform mole, $\mathrm{CH}$ - Complete hydatidiform mole, D-Diploid, CT- Cytotrophoblasts, VM - Villous Mesenchymal cells)

Of the 54 cases that were diagnosed as partial mole on review, $49(90 \%)$ were negative for p57KIP2 and were diploid. In the remaining five cases, two were negative for p57KIP2 and have no signals on FISH (case nos. 14, 21). Three cases expressed nuclear positivity only on cytotrophoblasts with no staining of the villous mesenchymal cells (case nos. 79,113, 122). Two of these cases were diploid and one showed no signals.

The interrater reliability between p57KIP2 and Her-2 FISH ploidy results is 0.66 ( $p<.0 .001), 95 \%$ CI $(0.02,1.00)$ which is considered "fair to good."

The kappa value between review diagnosis and p57KIP2 is 0.024 while the kappa between review diagnosis and Her-2 FISH ploidy is 0.050 both signifying poor agreement beyond chance.

\section{Discordant Cases}

Comparing the review histologic diagnosis with the results obtained in immunohistochemistry and FISH, 53 cases were found to have discordant results. $\mathrm{H}$ and $\mathrm{E}$ slides of these cases were reviewed using the morphologic parameters presented in Table 1 and correlated them with p57KIP2 and Her-2 ploidy status. The histologic diagnosis was revised in all 53 cases (Table 2).

\section{Discussion}

In the present study, we examined the usability of Her-2 FISH in determining the ploidy of hydatidiform mole cases by comparing it with immunohistochemical examination with p57KIP2. Histologic features of each type of hydatidiform mole as well as its most important differential diagnosis, hydropic placenta have been defined extensively and repeatedly. ${ }^{10,15,18-24}$ However, due to some overlaps in their morphology, discrimination among the three entities still continues to be a problem among pathologists, even to experts in the field.1,2,14,22 With the emergence of ultrasonography, detection and evacuation of molar pregnancy may be done at an even earlier phase giving rise to another entity designated as early complete mole $(\mathrm{eCH})-$ an addition to the list of differential diagnoses. ${ }^{14}$ Early $\mathrm{CH}$ has more subtle features than $\mathrm{CH}$ with few morphologic overlaps with $\mathrm{PH}$ to which it can easily be mistaken for. Thus, recognition may oftentimes be challenging. ${ }^{18}$

Because of the dilemma that pathologists constantly face when presented with hydropic placental products, they have scoured for different ways and means to increase accuracy in the diagnosis -- from re-evaluation of the traditional morphologic criteria to evaluation and validation of different complex methods at the molecular level. Among those which gave gained popularity among investigators are the combination of p57KIP2 immunohistochemistry and ploidy analysis by FISH. 4,5,13

p57KIP2 has been found to be helpful in many published studies. ${ }^{1-6,8,9,10,13,14,24,25}$ It can very well differentiate $\mathrm{CH}$ from $\mathrm{PH}$ but requires proper interpretation in terms of the type of trophoblasts to which it should be present and the level of expression. ${ }^{25}$ However, one of its drawbacks is that it cannot discriminate between $\mathrm{PH}$ and HA. Villi in both conditions will be positive for the test. An additional test such as a ploidy study is necessary to distinguished between the two. 
Ploidy analysis (either by FISH, CISH or flow cytometry) can differentiate between $\mathrm{PH}$ and $\mathrm{CH}$. $\mathrm{PH}$ will be triploid and $\mathrm{CH}$ will be diploid. It cannot however, discriminate $\mathrm{CM}$ from HA since both are diploid. FISH, the method we chose for this study, has three of powerful advantages: first, they do not require fresh specimen and can be used in archived material (FFPE and aspirate smears); second, it allows for correlation of FISH results with tissue morphology thus, the pathologist can easily identify which region of the section to be counted; third, it has a relatively fast turn-around time (2 days). ${ }^{16,26}$ But FISH analysis on FFPE is not always as simple. Preanalytical and analytical difficulties factors may be encountered that may have considerable effects in the quality of signals and thus the interpretation. Suboptimal fixation, longer storage time, inadequate masking of DNA and poor hybridization may result to weak or absent signals. ${ }^{4,16,26}$ Loss of signals were observed in 5 of our cases and this is attributed to suboptimal fixation.

In our study, there is good concordance between immunohistochemistry and FISH results in all our cases of $\mathrm{CH}$. p57KIP2 was positive in only one case of $\mathrm{PH}$ which was also triploid by Her-2 FISH. One case may not be enough for us to derive conclusions regarding the utility of both tests in $\mathrm{PH}$.

\section{Discordant cases}

Consistent with the experience of other pathologists, we also encountered difficulty in differentiating partial from complete mole based on morphology alone. $5,14,21,22$ Almost all of our cases with original and review diagnosis of $\mathrm{PH}$ were non-reactive to p57KIP2 and were diploid on Her-2 FISH except for one case. This means that all those cases, except for one, are $\mathrm{CH}$. They were diagnosed as $\mathrm{PH}$ because the following morphologic features of $\mathrm{PH}$ were observed: 1 . mixed population of large and small villi $(83 \%)$; 2. presence of trophoblastic inclusions (91\%); 3. presence of blood vessels $(47 \%) ; 4$. scalloped borders $(68 \%) ; 5$. mild to moderate trophoblastic proliferation. These are commonly used and published criteria for PH. $15,17,18,23,27,28,29$ Unfortunately, these features were also observed in CH. 12,17,22,30,31 Upon reviewing these cases, we noted that there were also features of $\mathrm{CH}$ that were present such as: 1 . trophoblastic atypia (94\%); 2 . marked hydropic changes in villi (89\%); 3. circumferential and/or multifocal trophoblastic proliferation in at least 2 villi $(92 \%) ; 4$. proliferation of the three types of trophoblasts: cyto-, syncytio-, and extravillous intermediate trophoblasts (81\%); 5. cistern formation (94\%).

\section{Trophoblastic atypia}

In Paradinas' paper, he included trophoblastic atypia as a finding in both $\mathrm{PH}$ and $\mathrm{CH}$ but he qualified further that it is a rarer finding in $\mathrm{PH}$ than in $\mathrm{CH}^{32,33}$ Thus, trophoblastic atypia alone is not a distinct feature of $\mathrm{CH}$. Other morphologic findings mentioned above must be present.

\section{Marked hydropic change}

Marked hydropic change was also observed by Fukunaga et al in PH. In his study, he measured the size of individual villi the greatest dimension reaching up to 6.5 $\mathrm{mm}$ with mean of $3.3 \mathrm{~mm} .{ }^{28}$ In our study, all but 6 cases $(11 \%)$ have at least one villi exhibiting marked hydropic change. Two of these cases were eCH (by AOG and morphology), two cases were possibly eCH exhibiting its classic features but information on AOG was not available for confirmation. In two cases, four features $(\# 1,3,4,5)$ of $\mathrm{CH}$ were present despite the absence of marked hydropic change. This would still warrant diagnosis of $\mathrm{CH}$. Adequacy of sampling is one factor to be looked at.

\section{Trophoblastic proliferation}

There are several contrasting views regarding pattern of trophoblastic proliferation. Howat used circumferential trophoblastic proliferation as one of the criteria for $\mathrm{PH} .{ }^{19}$ Shih et $\mathrm{al}^{17}$ and Chew et $\mathrm{al}^{34}$ on the other hand, considered circumferential trophoblastic proliferation as a feature of $\mathrm{PH}$ further qualifying that the degree of proliferation should be mild. On the other hand, Fukunaga recommended that circumferential trophoblastic proliferation observed in at least two villi warrants diagnosis of $\mathrm{CH}$ even if the degree of trophoblastic proliferation is mild. ${ }^{28}$ In this study, circumferential and/or multifocal trophoblastic proliferation in at least two villi were seen in $92 \%$ of cases regardless of the degree of trophoblastic proliferation and $81 \%$ have proliferation of the three types of trophoblasts.

\section{Cistern formation}

Cistern formation, in our opinion, was a non-specific finding as it may be observed in $\mathrm{CH}$ and $\mathrm{PH}$ and $\mathrm{HA} \cdot{ }^{31}$ One study claimed to have observed it in $98 \%$ of its cases of $\mathrm{PH} .{ }^{28}$

It is quite taxing to pinpoint which among these criteria can reliably discriminate $\mathrm{CH}$ from $\mathrm{PH}$. It seems that the appropriateness of the criteria is not only the sole problem for the discordance but also pathologist's interpretation of the criteria and how he/she applies them. The adequacy of sampling is an important factor as well. ${ }^{21}$ During our initial review of all the cases, we have given more weight on the heterogeneity of the villus population and mild to moderate trophoblastic proliferation especially if they were accompanied by trophoblastic inclusions and blood vessels. We have underestimated the presence of important features of $\mathrm{CH}$ especially if the extent of involvement was just focal. In retrospect, based from our observations, the combination of trophoblastic atypia, marked hydropic villous change and circumferential trophoblastic proliferation in as few as two villi even in a specimen with heterogenous population is most likely a $\mathrm{CH}$. eCH should be suspected if one criterion is not observed. Look for the characteristic myxoid hypercellular stroma and confirm the age of gestation. Based on our experience, $\mathrm{CH}$ appears to occur at a higher rate than 
$\mathrm{PH}$; hence, the possibility of a $\mathrm{CH}$ or an $\mathrm{eCH}$ should be ruled out first before rendering a diagnosis of $\mathrm{PH}$.

\section{P57kip2 staining pattern}

We also encountered variations in p57KIP2 in three cases. Nuclear reactivity was observed only on the cytotrophoblasts and not on villous mesenchymal cells. Similar cases have been encountered in other studies and were regarded as possible cases of placental mosaicism. ${ }^{12,35}$ Cytogenetic studies, however, are required for confirmation. Two of the cases were diploid and exhibited marked hydropic change, circumferential trophoblastic proliferation of cyto- and syncytiotrophoblasts, trophoblastic atypia and cistern formation. Thus, both cases were classified under $\mathrm{CH}$. The other case has no readable signals on Her-2 FISH but reevaluation of morphology revealed it has multifocal and circumferential proliferation of the three types of trophoblasts, trophoblastic atypia and cistern formation. The morphologic features are compatible with $\mathrm{CH}$.

There were two cases that were negative for p57KIP2 and no signals were seen on Her-2 FISH. Morphologic features include predominantly large villi with marked hydropic changes, circumferential trophoblastic proliferation of three types of trophoblasts, trophoblastic atypia and cistern formation. The final diagnosis for both cases was $\mathrm{CH}$.

\section{Conclusion}

As anatomic pathologists, we believe that morphologic examination of a tumor is still the best method to render a diagnosis. Hence, one should try to the best of his abilities to render an accurate histologic diagnosis. However, in this study, we have once again proven the limitations of morphologic assessment alone. The use of ancillary techniques for problematic cases is highly recommended. There is no single ancillary technique that can discriminate between $\mathrm{HA}, \mathrm{PH}, \mathrm{eCH}$ and $\mathrm{CH}$. Two complementary methods such as p57KIP2 immunohistochemistry and ploidy study (using Her-2 or other probes as well) should be used.

We have shown in our study that DNA ploidy analysis using Her-2 FISH probe is practical and accurate adjunct to immunohistochemical staining with p57KIP2 immunohistochemistry in the diagnosis of complete hydatidiform mole. However, further studies with more number of $\mathrm{PH}$ cases should be done to confirm its utility in PH. Her-2 FISH in conjunction with p57KIP2 immunohistochemistry and morphology creates a synergistic effect in clinching the diagnosis.

\section{References}

1. Blaustein's Pathology of the Female Genital Tract, $6^{\text {th }}$ ed. Kurman RJ, Ellenson LH, Ronette B, eds. 2011. pp. 540-541.

2. Madi JM, Braga $\mathrm{AR}^{4}$, Paganella MP, Litvin IE, Da Ros Wendland EM. Accuracy of p57KIP2 compared with genotyping for the diagnosis of complete hydatidiform mole: protocol for a systematic review and metaanalysis. Syst Rev. 2016; 5(1):169.
3. Heidarpour M, Khanahmadi M. Diagnostic value of p63 in differentiating normal gestation from molar pregnancy. J Res Med Sci. 2013; 18(6):462-6.

4. LeGallo RD, Stelow EB, Ramirez NC, Atkins KA. Diagnosis of hydatidiform moles using p57 immunohistochemistry and HER-2 fluorescent in situ hybridization. Am J Clin Pathol. 2008; 129(5):749-55.

5. Crisp H, Burton JL, Stewart R, Wells M. Refining the diagnosis of hydatidiform mole: image ploidy analysis and p57KIP2 immunohistochemistry. Histopathology. 2003; 43(4):363-73.

6. Castrillon DH, Sun D, Weremowicz S, Fisher RA, Crum CP, Genest DR. Discrimination of complete hydatidiform mole from its mimics by immunohistochemistry of the paternally imprinted gene product p57KIP2. Am J Surg Pathol. 2001; 25(10):1225-30.

7. Bifulco C, Johnson C, Hao L, Kermalli H, Bell S, Hui P. Genotypic analysis of hydatidiform mole: an accurate and practical method of diagnosis. Am J Surg Pathol. 2008; 32(3):445-51.

8. Soma H, Osawa H, Oguro T, et al. P57kip2 immunohistochemical expression and ultrastructural findings of gestational trophoblastic disease and related disorders. Med Mol Morphol. 2007; 40(2):95-102.

9. Popiolek DA, Yee H, Mittal K, et al., Multiplex short tandem repeat DNA analysis confirms the accuracy of p57(KIP2) immunostaining in the diagnosis of complete hydatidiform mole. Hum Pathol. 2006; 37(11):1426-34.

10. Maggiori MS, Peres LC. Morphological, immunohistochemical and chromosome in situ hybridization in the differential diagnosis of Hydatidiform Mole and Hydropic Abortion. Eur J Obstet Gynecol Reprod Biol. 2007; 135(2):170-6.

11. Lash GE, Quenby S, Burton GJ. Gestational diseases -- a workshop report. Placenta. 2008; 29Suppl A:S92-4.

12. McConnell TG, Murphy KM, Hafez M, Vang R, Ronnett BM. Diagnosis and subclassification of hydatidiform moles using p57 immunohistochemistry and molecular genotyping: validation and prospective analysis in routine and consultation practice settings with development of an algorithmic approach. Am J Surg Pathol. 2009; 33(6):805-17.

13. Jun SY, Ro JY, Kim KR. p57KIP2 is useful in the classification and differential diagnosis of complete and partial hydatidiform moles. Histopathology. 2003; 43(1):17-25.

14. Merchant SH, Amin MB, Viswanatha DS, Malhotra RK, Moehlenkamp C, Joste NE. p57KIP2 immunohistochemistry in early molar pregnancies: emphasis on its complementary role in the differential diagnosis of hydropic abortuses. Hum Pathol. 2005; 36(2):180-6.

15. Cheung A. Gestational Trophoblastic Disease. In: Robboy S, et al., eds. Pathology of the Female Reproductive Tract. Churchill Livingstone; 2009. pp. 881-907.

16. Cheville JC, Greiner T, Robinson RA, Benda JA. Ploidy analysis by flow cytometry and fluorescence in situ hybridization in hydropic placentas and gestational trophoblastic disease. Hum Pathol. 1995; 26(7):753-7.

17. Shih LM, Mazur MT, Kurman RJ. Gestational Trophoblastic Disease and Related Lesions. In: Kurman RJ, ed. Kuhrman's Pathology of the Female Genital Tract. Springer; 2002. pp. 1209 - 1217.

18. Elvin JA, Crum CP, Genest DR. Complications of Early Pregnancy, Including Trophoblastic Neoplasia. In: Crum C, Lee K, eds. Diagnostic Gynecologic and Obstetric Pathology. Elsevier Saunders; 2006. pp. 10151037.

19. Howat AJ, Beck S, Fox H, et al. Can histopathologists reliably diagnose molar pregnancy? J Clin Pathol. 1993; 46(7):599-602.

20. Hayati AR, Tan GC. Clinicopathologic and immunohistochemical differences in complete and partial hydatidiform moles in a multiracial Malaysian population. Int J Gynecol Pathol. 2005; 24(3):277-85.

21. Fukunaga M, Katabuchi H, Nagasaka T, Mikami Y, Minamiguchi S, Lage JM. Interobserver and intraobserver variability in the diagnosis of hydatidiform mole. Am J Surg Pathol. 2005; 29(7):942-7.

22. Sumithran E, Cheah PL, Susil BJ, Looi LM. Problems in the histological assessment of hydatidiform moles: a study on consensus diagnosis and ploidy status by fluorescent in situ hybridisation. Pathology. 1996; 28(4):311-5.

23. Genest D, et al., Gestational Trophoblastic Disease. In: Tavassoli FA, Devilee P, eds. WHO Tumors of Breast and Female Genital Organs. IARC Press; 2003. pp. 250 - 254. 
24. Kihara M, Matsui H, Seki K, Nagai Y, Wake N, Sekiya S. Genetic origin and imprinting in hydatidiform moles. Comparison between DNA polymorphism analysis and immunoreactivity of p57KIP2. J Reprod Med. 2005; 50(5):307-12.

25. Sebire NJ, Lindsay I. p57KIP2 immunostaining in the diagnosis of complete versus partial hydatidiform moles. Histopathology. 2006; 48(7):873-4.

26. Cook JR. Fluorescence In Situ Hybridization. In: Tubbs RR, Stoler MH, eds. Cellular and Tissue Based Molecular Pathology. Churchill Livingstone Elsevier; 2009. pp. 104-113.

27. Niemann I, Hansen ES, Sunde L. The risk of persistent trophoblastic disease after hydatidiform mole classified by morphology and ploidy. Gynecol Oncol, 2007; 104(2): 411-5.

28. Fukunaga M. Histopathologic study of partial hydatidiform moles and DNA triploid placentas. Pathol Int. 1994; 44(7):528-34

29. Genest DR. Partial hydatidiform mole: clinicopathological features, differential diagnosis, ploidy and molecular studies, and gold standards for diagnosis. Int J Gynecol Pathol. 2001; 20(4):315-22.

30. Ishikawa N, Harada Y, Tokuyasu Y, Nagasaki M, Maruyama R. Reevaluation of the histological criteria for complete hydatidiform mole: comparison with the immunohistochemical diagnosis using p57KIP2 and CD 34. Biomed Res. 2009; 30(3):141-7.
31. Yver M, Carles D, Bloch B, Bioulac-Sage P, Martin Negrier ML. Determination of DNA ploidy by fluorescence in situ hybridization (FISH) in hydatidiform moles: evaluation of FISH on isolated nuclei. Hum Pathol. 2004; 35(6):752-8.

32. Gschwendtner A, Neher A, Kreczy A, Müller-Holzner E, Volgger B, Mairinger T. DNA ploidy determination of early molar pregnancies by image analysis: comparison to histologic classification. Arch Pathol Lab Med. 1998; 122(11):1000-4

33. Paradinas FJ. The histological diagnosis of hydatidiform moles. Curr Diagn Pathol. 1994; 1:24-31.

34. Chew SH, Perlman EJ, Williams R, Kurman RJ, Ronnett BM. Morphology and DNA content analysis in the evaluation of first trimester placentas for partial hydatidiform mole (PHM). Hum Pathol. 2000; 31(8):914-24.

35. Hoffner L, Dunn J, Esposito N, Macpherson T, Surti U. P57KIP2 immunostaining and molecular cytogenetics: combined approach aids in diagnosis of morphologically challenging cases with molar phenotype and in detecting androgenetic cell lines in mosaic/chimeric conceptions. Hum Pathol. 2008; 39(1):63-72.

\section{Appendix}

Histologic diagnosis, immunohistochemical and ploidy analyses of all cases

\begin{tabular}{|c|c|c|c|c|c|}
\hline $\begin{array}{l}\text { Case } \\
\text { No. }\end{array}$ & $\begin{array}{c}\text { Original } \\
\text { Diagnosis }\end{array}$ & $\begin{array}{c}\text { Review } \\
\text { Diagnosis }\end{array}$ & $\begin{array}{l}\text { p57KIP2 } \\
\text { staining }\end{array}$ & $\begin{array}{l}\text { Her-2 } \\
\text { FISH }\end{array}$ & $\begin{array}{c}\text { Final } \\
\text { Diagnosis }\end{array}$ \\
\hline 1 & H. mole & $\mathrm{CH}$ & - & $\mathrm{D}$ & $\mathrm{CH}$ \\
\hline 2 & $\begin{array}{c}\text { Consistent } \\
\text { with H. mole }\end{array}$ & $\mathrm{CH}$ & - & $\mathrm{D}$ & $\mathrm{CH}$ \\
\hline 3 & H. mole & $\mathrm{CH}$ & - & $\mathrm{D}$ & $\mathrm{CH}$ \\
\hline 4 & H. mole & $\mathrm{CH}$ & - & $\mathrm{D}$ & $\mathrm{CH}$ \\
\hline 5 & $\mathrm{CH}$ & $\mathrm{CH}$ & - & $\mathrm{D}$ & $\mathrm{CH}$ \\
\hline 6 & $\mathrm{CH}$ & $\mathrm{CH}$ & - & $\mathrm{D}$ & $\mathrm{CH}$ \\
\hline 7 & H. mole & $\mathrm{CH}$ & - & $\mathrm{D}$ & $\mathrm{CH}$ \\
\hline 8 & H. mole & $\mathrm{CH}$ & - & $\mathrm{D}$ & $\mathrm{CH}$ \\
\hline 9 & $\mathrm{CH}$ & $\mathrm{CH}$ & - & $\mathrm{D}$ & $\mathrm{CH}$ \\
\hline $10^{*}$ & $\mathrm{PH}$ & $\mathrm{PH}$ & - & $\mathrm{D}$ & $\mathrm{CH}$ \\
\hline 11 & $\mathrm{CH}$ & $\mathrm{CH}$ & - & $\mathrm{D}$ & $\mathrm{CH}$ \\
\hline 12 & $\mathrm{CH}$ & $\mathrm{CH}$ & - & $\mathrm{D}$ & $\mathrm{CH}$ \\
\hline 13 & $\begin{array}{l}\text { Products of } \\
\text { conception }\end{array}$ & $\mathrm{PH}$ & + & $\mathrm{T}$ & $\mathrm{PH}$ \\
\hline $14^{*}$ & $\mathrm{CH}$ & $\mathrm{PH}$ & - & No signal & $\mathrm{CH}$ \\
\hline 15 & $\mathrm{PH}$ & $\mathrm{CH}$ & - & $\mathrm{D}$ & $\mathrm{CH}$ \\
\hline $16^{*}$ & H. mole & $\mathrm{PH}$ & - & $\mathrm{D}$ & $\mathrm{CH}$ \\
\hline 17 & $\mathrm{PH}$ & $\mathrm{CH}$ & - & $\mathrm{D}$ & $\mathrm{CH}$ \\
\hline 18 & $\mathrm{CH}$ & $\mathrm{CH}$ & - & $\mathrm{D}$ & $\mathrm{CH}$ \\
\hline 19 & $\mathrm{CH}$ & $\mathrm{CH}$ & - & $\mathrm{D}$ & $\mathrm{CH}$ \\
\hline 20 & $\mathrm{CH}$ & $\mathrm{CH}$ & - & $\mathrm{D}$ & $\mathrm{CH}$ \\
\hline 21 & $\mathrm{CH}$ & $\mathrm{CH}$ & - & No signal & $\mathrm{CH}$ \\
\hline 22 & $\mathrm{CH}$ & $\mathrm{CH}$ & - & $\mathrm{D}$ & $\mathrm{CH}$ \\
\hline 23 & $\mathrm{CH}$ & $\mathrm{CH}$ & - & $\mathrm{D}$ & $\mathrm{CH}$ \\
\hline 24 & $\mathrm{CH}$ & $\mathrm{CH}$ & - & $\mathrm{D}$ & $\mathrm{CH}$ \\
\hline 25 & $\mathrm{CH}$ & $\mathrm{CH}$ & - & $\mathrm{D}$ & $\mathrm{CH}$ \\
\hline 26 & $\mathrm{PH}$ & $\mathrm{CH}$ & - & $\mathrm{D}$ & $\mathrm{CH}$ \\
\hline $27^{*}$ & $\mathrm{PH}$ & $\mathrm{PH}$ & - & $\mathrm{D}$ & $\mathrm{CH}$ \\
\hline 28 & $\mathrm{CH}$ & $\mathrm{CH}$ & - & $\mathrm{D}$ & $\mathrm{CH}$ \\
\hline $29^{*}$ & $\mathrm{CH}$ & $\mathrm{PH}$ & - & $\mathrm{D}$ & $\mathrm{CH}$ \\
\hline 30 & $\mathrm{CH}$ & $\mathrm{CH}$ & - & D & $\mathrm{CH}$ \\
\hline $31^{*}$ & $\mathrm{CH}$ & $\mathrm{PH}$ & - & $\mathrm{D}$ & $\mathrm{CH}$ \\
\hline 32 & $\mathrm{CH}$ & $\mathrm{CH}$ & - & $\mathrm{D}$ & $\mathrm{CH}$ \\
\hline $33^{*}$ & $\mathrm{CH}$ & $\mathrm{PH}$ & - & D & $\mathrm{CH}$ \\
\hline 34 & $\mathrm{CH}$ & $\mathrm{CH}$ & - & D & $\mathrm{CH}$ \\
\hline 35 & $\mathrm{CH}$ & $\mathrm{CH}$ & - & D & $\mathrm{CH}$ \\
\hline 36 & $\mathrm{CH}$ & $\mathrm{CH}$ & - & $\mathrm{D}$ & $\mathrm{CH}$ \\
\hline 37 & $\mathrm{CH}$ & $\mathrm{CH}$ & - & $\mathrm{D}$ & $\mathrm{CH}$ \\
\hline $38^{*}$ & $\mathrm{CH}$ & $\mathrm{PH}$ & - & D & $\mathrm{CH}$ \\
\hline
\end{tabular}

\begin{tabular}{|c|c|c|c|c|c|}
\hline 39 & $\mathrm{CH}$ & $\mathrm{CH}$ & - & $\mathrm{D}$ & $\mathrm{CH}$ \\
\hline $40^{*}$ & $\mathrm{CH}$ & $\mathrm{PH}$ & - & $\mathrm{D}$ & $\mathrm{CH}$ \\
\hline $41^{*}$ & $\mathrm{CH}$ & $\mathrm{PH}$ & - & $\mathrm{D}$ & $\mathrm{CH}$ \\
\hline 42 & $\mathrm{CH}$ & $\mathrm{CH}$ & - & D & $\mathrm{CH}$ \\
\hline 43 & $\mathrm{CH}$ & $\mathrm{CH}$ & - & $\mathrm{D}$ & $\mathrm{CH}$ \\
\hline 44 & $\mathrm{CH}$ & $\mathrm{CH}$ & - & $\mathrm{D}$ & $\mathrm{CH}$ \\
\hline 45 & $\mathrm{CH}$ & $\mathrm{CH}$ & - & $\mathrm{D}$ & $\mathrm{CH}$ \\
\hline 46 & $\mathrm{CH}$ & $\mathrm{CH}$ & - & $\mathrm{D}$ & $\mathrm{CH}$ \\
\hline 47 & $\mathrm{CH}$ & $\mathrm{CH}$ & - & $\mathrm{D}$ & $\mathrm{CH}$ \\
\hline 48 & $\mathrm{CH}$ & $\mathrm{CH}$ & - & $\mathrm{D}$ & $\mathrm{CH}$ \\
\hline 49 & $\mathrm{CH}$ & $\mathrm{CH}$ & - & D & $\mathrm{CH}$ \\
\hline 50 & $\mathrm{CH}$ & $\mathrm{CH}$ & - & $\mathrm{D}$ & $\mathrm{CH}$ \\
\hline 51 & $\mathrm{CH}$ & $\mathrm{CH}$ & - & $\mathrm{D}$ & $\mathrm{CH}$ \\
\hline 52 & $\mathrm{CH}$ & $\mathrm{CH}$ & - & $\mathrm{D}$ & $\mathrm{CH}$ \\
\hline 53 & $\mathrm{CH}$ & $\mathrm{CH}$ & - & D & $\mathrm{CH}$ \\
\hline $54^{*}$ & $\mathrm{CH}$ & $\mathrm{PH}$ & - & D & $\mathrm{CH}$ \\
\hline 55 & $\mathrm{CH}$ & $\mathrm{CH}$ & - & $\mathrm{D}$ & $\mathrm{CH}$ \\
\hline 56 & $\mathrm{CH}$ & $\mathrm{CH}$ & - & D & $\mathrm{CH}$ \\
\hline 57 & $\mathrm{CH}$ & $\mathrm{CH}$ & - & $\mathrm{D}$ & $\mathrm{CH}$ \\
\hline 58 & $\mathrm{CH}$ & $\mathrm{CH}$ & - & $\mathrm{D}$ & $\mathrm{CH}$ \\
\hline 59 & $\mathrm{CH}$ & $\mathrm{CH}$ & - & D & $\mathrm{CH}$ \\
\hline 60 & $\mathrm{CH}$ & $\mathrm{CH}$ & - & $\mathrm{D}$ & $\mathrm{CH}$ \\
\hline 61 & $\mathrm{CH}$ & $\mathrm{CH}$ & - & $\mathrm{D}$ & $\mathrm{CH}$ \\
\hline 62 & $\mathrm{CH}$ & $\mathrm{CH}$ & - & D & $\mathrm{CH}$ \\
\hline 63 & $\mathrm{CH}$ & $\mathrm{CH}$ & - & D & $\mathrm{CH}$ \\
\hline $64^{*}$ & $\mathrm{CH}$ & $\mathrm{PH}$ & - & D & $\mathrm{CH}$ \\
\hline 65 & $\mathrm{CH}$ & $\mathrm{CH}$ & - & D & $\mathrm{CH}$ \\
\hline 66 & $\mathrm{CH}$ & $\mathrm{CH}$ & - & $\mathrm{D}$ & $\mathrm{CH}$ \\
\hline 67 & $\mathrm{CH}$ & $\mathrm{CH}$ & - & D & $\mathrm{CH}$ \\
\hline 68 & $\mathrm{CH}$ & $\mathrm{CH}$ & - & $\mathrm{D}$ & $\mathrm{CH}$ \\
\hline 69 & $\mathrm{CH}$ & $\mathrm{CH}$ & - & $\mathrm{D}$ & $\mathrm{CH}$ \\
\hline 70 & $\mathrm{CH}$ & $\mathrm{CH}$ & - & D & $\mathrm{CH}$ \\
\hline 71 & $\mathrm{CH}$ & $\mathrm{CH}$ & - & D & $\mathrm{CH}$ \\
\hline $72^{*}$ & $\mathrm{CH}$ & $\mathrm{PH}$ & - & $\mathrm{D}$ & $\mathrm{CH}$ \\
\hline 73 & $\mathrm{CH}$ & $\mathrm{CH}$ & - & $\mathrm{D}$ & $\mathrm{CH}$ \\
\hline $74^{*}$ & $\mathrm{CH}$ & $\mathrm{PH}$ & - & $\mathrm{D}$ & $\mathrm{CH}$ \\
\hline 75 & $\mathrm{CH}$ & $\mathrm{CH}$ & - & D & $\mathrm{CH}$ \\
\hline 76 & $\mathrm{CH}$ & $\mathrm{CH}$ & - & $\mathrm{D}$ & $\mathrm{CH}$ \\
\hline 77 & $\mathrm{CH}$ & $\mathrm{CH}$ & - & $\mathrm{D}$ & $\mathrm{CH}$ \\
\hline 78 & $\mathrm{PH}$ & $\mathrm{CH}$ & - & D & $\mathrm{CH}$ \\
\hline $79^{*}$ & $\mathrm{PH}$ & $\mathrm{PH}$ & (+) CT (-) VM & No Signal & $\mathrm{CH}$ \\
\hline $80^{*}$ & $\mathrm{PH}$ & $\mathrm{PH}$ & - & $\mathrm{D}$ & $\mathrm{CH}$ \\
\hline
\end{tabular}


p57KIP2, A Reliable Tool in Differentiating Complete from Partial Hydatidiform Mole

\begin{tabular}{llllll}
\hline $81^{*}$ & PH & PH & - & D & CH \\
$82^{*}$ & PH & PH & - & D & CH \\
$83^{*}$ & PH & PH & - & D & CH \\
84 & PH & CH & - & D & CH \\
85 & PH & CH & - & D & $\mathrm{CH}$ \\
$86^{*}$ & $\mathrm{PH}$ & $\mathrm{PH}$ & - & D & $\mathrm{CH}$ \\
87 & $\mathrm{PH}$ & $\mathrm{CH}$ & - & $\mathrm{D}$ & $\mathrm{CH}$ \\
$88^{*}$ & $\mathrm{PH}$ & $\mathrm{PH}$ & - & $\mathrm{D}$ & $\mathrm{CH}$ \\
$89^{*}$ & $\mathrm{PH}$ & $\mathrm{PH}$ & - & $\mathrm{D}$ & $\mathrm{CH}$ \\
$90^{*}$ & $\mathrm{PH}$ & $\mathrm{PH}$ & - & $\mathrm{D}$ & $\mathrm{CH}$ \\
$91^{*}$ & $\mathrm{PH}$ & $\mathrm{PH}$ & - & $\mathrm{D}$ & $\mathrm{CH}$ \\
92 & $\mathrm{PH}$ & $\mathrm{PH}$ & - & $\mathrm{D}$ & $\mathrm{CH}$ \\
$93^{*}$ & $\mathrm{PH}$ & $\mathrm{PH}$ & - & $\mathrm{D}$ & $\mathrm{CH}$ \\
$94^{*}$ & $\mathrm{PH}$ & $\mathrm{PH}$ & - & $\mathrm{D}$ & $\mathrm{CH}$ \\
$95^{*}$ & $\mathrm{PH}$ & $\mathrm{PH}$ & - & $\mathrm{D}$ & $\mathrm{CH}$ \\
96 & $\mathrm{PH}$ & $\mathrm{CH}$ & - & $\mathrm{D}$ & $\mathrm{CH}$ \\
$97^{*}$ & $\mathrm{PH}$ & $\mathrm{PH}$ & - & $\mathrm{D}$ & $\mathrm{CH}$ \\
$98^{*}$ & $\mathrm{PH}$ & $\mathrm{PH}$ & - & No signal & $\mathrm{CH}$ \\
$99^{*}$ & $\mathrm{PH}$ & $\mathrm{PH}$ & - & $\mathrm{D}$ & $\mathrm{CH}$ \\
$100^{*}$ & $\mathrm{PH}$ & $\mathrm{PH}$ & - & $\mathrm{D}$ & $\mathrm{CH}$ \\
$101^{*}$ & $\mathrm{PH}$ & $\mathrm{PH}$ & - & $\mathrm{D}$ & $\mathrm{CH}$ \\
$102^{*}$ & $\mathrm{PH}$ & $\mathrm{PH}$ & - & $\mathrm{D}$ & $\mathrm{CH}$ \\
\hline
\end{tabular}

\begin{tabular}{|c|c|c|c|c|c|}
\hline $103^{*}$ & $\mathrm{PH}$ & $\mathrm{PH}$ & - & $\mathrm{D}$ & $\mathrm{CH}$ \\
\hline $104^{*}$ & $\mathrm{PH}$ & $\mathrm{PH}$ & - & D & $\mathrm{CH}$ \\
\hline $105^{*}$ & PH & PH & - & D & $\mathrm{CH}$ \\
\hline $106^{*}$ & $\mathrm{PH}$ & $\mathrm{PH}$ & - & D & $\mathrm{CH}$ \\
\hline $107^{*}$ & $\mathrm{PH}$ & $\mathrm{PH}$ & - & D & $\mathrm{CH}$ \\
\hline $108^{*}$ & $\mathrm{PH}$ & $\mathrm{PH}$ & - & $\mathrm{D}$ & $\mathrm{CH}$ \\
\hline $109^{*}$ & $\mathrm{PH}$ & PH & - & D & $\mathrm{CH}$ \\
\hline $110^{*}$ & $\mathrm{PH}$ & $\mathrm{PH}$ & - & D & $\mathrm{CH}$ \\
\hline $111^{*}$ & $\mathrm{PH}$ & $\mathrm{PH}$ & - & $\mathrm{D}$ & $\mathrm{CH}$ \\
\hline $112^{*}$ & $\mathrm{PH}$ & PH & - & D & $\mathrm{CH}$ \\
\hline $113^{*}$ & $\mathrm{PH}$ & PH & (+) CT (-) VM & $\mathrm{D}$ & $\mathrm{CH}$ \\
\hline $114^{*}$ & $\mathrm{PH}$ & $\mathrm{PH}$ & - & D & $\mathrm{CH}$ \\
\hline $115^{*}$ & $\mathrm{PH}$ & $\mathrm{PH}$ & - & D & $\mathrm{CH}$ \\
\hline $116^{*}$ & $\mathrm{PH}$ & $\mathrm{PH}$ & - & D & $\mathrm{CH}$ \\
\hline $117^{*}$ & $\mathrm{PH}$ & $\mathrm{PH}$ & - & D & $\mathrm{CH}$ \\
\hline $118^{*}$ & $\mathrm{PH}$ & $\mathrm{PH}$ & - & D & $\mathrm{CH}$ \\
\hline $119^{*}$ & $\mathrm{PH}$ & $\mathrm{PH}$ & - & D & $\mathrm{CH}$ \\
\hline $120^{*}$ & $\mathrm{PH}$ & $\mathrm{PH}$ & - & D & $\mathrm{CH}$ \\
\hline $121^{*}$ & $\mathrm{PH}$ & $\mathrm{PH}$ & - & No Signal & $\mathrm{CH}$ \\
\hline $122^{*}$ & $\mathrm{PH}$ & $\mathrm{PH}$ & (+) CT (-) VM & D & $\mathrm{CH}$ \\
\hline
\end{tabular}

* Discordant cases. 